\title{
Stratigraphy of the Koivusaarenneva exposure and its correlation across central Ostrobothnia, Finland
}

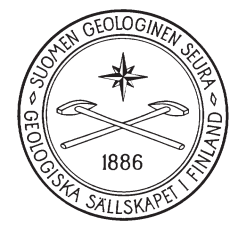

VERTAISARVIOITU KOLLEGIALT GRANSKA
PEER-REVIEWED
www.tsv.fi/tunnus

\author{
Juha Pekka Lunkka ${ }^{\mathrm{I}^{*}}$, Petri Lintinen ${ }^{2}$, Keijo Nenonen ${ }^{2}$, \\ Pekka Huhta² \\ ${ }^{1}$ Oulu Mining School, P.O. Box 3000, FI-90014 University of Oulu, Finland \\ ${ }^{2}$ Geological Survey of Finland, P.O. Box 96, FI-02151 Espoo, Finland
}

\begin{abstract}
A multiple till succession at Koivusaarenneva in Central Ostrobothnia, adjacent to the Gulf of Bothnia, was studied using conventional sedimentological techniques. In addition, a sand-rich unit between two till beds was dated by the Optical Stimulated Luminescence (OSL) method and organic-bearing silt was subjected to pollen analysis. The methods were applied to determine the Pleistocene sedimentation history of the area. The results obtained indicate that the lowest till above the crystalline bedrock at Koivusaarenneva was deposited from the NNW during the Saalian glaciation, whereas the organic-bearing sediments and deformed sand and silt above, were laid down during the Eemian and the Early Weichselian stages. Two till beds above the Early Weichselian sediments indicate that at least two separate Scandinavian Ice Sheet advances took place in the area, most likely in the early Middle Weichselian and the Late Weichselian substages.
\end{abstract}

Keywords: stratigraphy, Weichselian, Scandinavian Ice Sheet, OSL dating, Central Ostrobothnia

*Corresponding author (e-mail: juha.pekka.lunkka@oulu.fi)

Editorial handling: Pertti Sarala (pertti.sarala@gtk.fi) 


\section{Introduction}

The Middle and Late Pleistocene glacial history of Finland and its adjacent areas is mainly based on lithostratigraphical and biostratigraphical evidence from terrestrial sediment exposures. In addition to this evidence, geochronological methods, such as thermo- and optical stimulated luminescence methods (TL and OSL) and radiocarbon dating $\left({ }^{14} \mathrm{C}\right)$, have also been widely applied during the past decades for chronostratigraphical correlation to obtain a temporal control of the repeated events of glacial coverage from the Scandinavian Ice Sheet (SIS) (cf. Donner, 1995; Nenonen, 1995; Svendsen et al., 2004; Lunkka et al., 2004; Larsen et al., 2006; Johansson et al., 2011; Wohlfarth, 2013; Helmens, 2014). Most of Finland, located east of the former ice dome areas of the SIS, is in a crucial location for studying major waxing and waning events of the SIS through time - although several ice advance events across the area have caused erosion and subglacial deformation of previously deposited sediments. Therefore, most of the pre-Late Weichselian sediments have been completely eroded or severely glaciotectonised. However, in central Finnish Lapland and in Ostrobothnia, there are more abundant occurrences of pre-Late Weichselian sediments underlying the Late Weichselian till, compared to the rest of Finland. It is assumed that this preservation of older sediments is related to the postulated 'frozen bed' conditions of the SIS in these areas during the Last Glacial Maximum (LGM) (Kleman \& Hättesrand, 1999). Subsequently they would be less affected along the ice-bed interface (e.g. Boulton et al., 2009). However, in Ostrobothnia, where pre-LGM sediments are common, it may also have been the case that the pre-LGM sediment cover (mainly sand and silt strata) was sufficiently thick to enable subglacial deformation, and under favourable conditions minimize glacial erosion (cf. Iverson, 2010), during the LGM and the last deglaciation.

The sediment record representing the SIS history at each site studied in Finland so far remains fragmentary. Still, a broad picture of the events that took place in western and southern Finland and adjacent areas to the east during the Late Pleistocene is relatively well established (Nenonen, 1995; Lunkka et al., 2004; Svendsen et al., 2004; Lunkka et al., 2008; Salonen et al., 2008; Pitkäranta et al., 2013; Johansson et al., 2011; Larsen et al., 2014). However, there are still unresolved and disputed questions relating to the glaciation history of Finland. These include, for example, the questions such as the number and dynamics of the Weichselian ice advances into and across the country and adjacent areas to the east, their extent, and the length of ice free periods between glacial phases.

In essence, there are two extreme hypotheses of the glaciation history of Finland. One of these is the so-called 'monoglacial' hypothesis of Forsström (1984) and Punkari \& Forsström (1995) for example. These authors claim that the SIS covered Finland for most of Weichselian time. They also suggest that most, if not all, the organic matter and sorted sediment units found beneath the Late Weichselian till are reworked and cannot, therefore, be used for stratigraphical purposes. Another extremist hypothesis was recently introduced by Räsänen et al. (2015) who came to the conclusion that Finland had been ice free from the beginning of the Eemian Stage interglacial until the Late Weichselian.

In western Finland, namely in the Ostrobothnian area adjacent to the Gulf of Bothnia (Fig. 1), there are a number of localities where interglacial/ interstadial Middle and Late Pleistocene sediments have survived glacial erosion (Johansson et al., 2011), in spite being glaciotectonically deformed to various degrees at most sites investigated. However, nowhere in Ostrobothnia has any site been found where all the recognised pre-Weichselian/ Weichselian till units (representing ice coverage) occurred in superposition, separated by interglacial/ interstadial sediments. Thus a scheme of ice advances across the area remains unclear and dependant on correlation between different stratigraphical localities. However, results of previous investigations suggest that the southern and western parts of 
Finland were ice free during the Mid-Saalian (Marine Isotope Stage, MIS 7) (Salonen et al., 1992), and from the Eemian Interglacial through to the end of the Odderade Interstadial of the Early Weichselian substage (MIS 5e-MIS 5a) (Nenonen, 1995; Saarnisto \& Salonen, 1995; Saarnisto \& Lunkka, 2004; Lunkka et al., 2004; Sarala, 2005; Salonen et al., 2008; Johansson et al., 2011). In addition, ice-free period(s) has (have) also occurred during the latter part of the Middle Weichselian (MIS 3) (Ukkonen et al., 1999; Lunkka et al., 2001; Svendsen et al., 2004; Salonen et al., 2008) and following the last deglaciation that took place in the area c. 10 ka ago (Johansson et al., 2011; Cuzzone et al., 2016). In terms of SIS advances this implies that, after the Warthe Substage (MIS 6) of the Saalian Glaciation, the SIS advanced into western Finland across the Gulf of Bothnia (i) at the beginning of the Middle Weichselian ( $\sim$ MIS 4), (ii) at least once during the latter part of the Middle Weichselian (c. MIS 3) and, finally, (iii) during the Late Weichselian (MIS 2). However, recently Pitkäranta et al. (2013) suggested that the first Weichselian SIS ice advance into southern Ostrobothnian area took place as early as the Early Weichselian (the Herning Interstadial, MIS 5d).

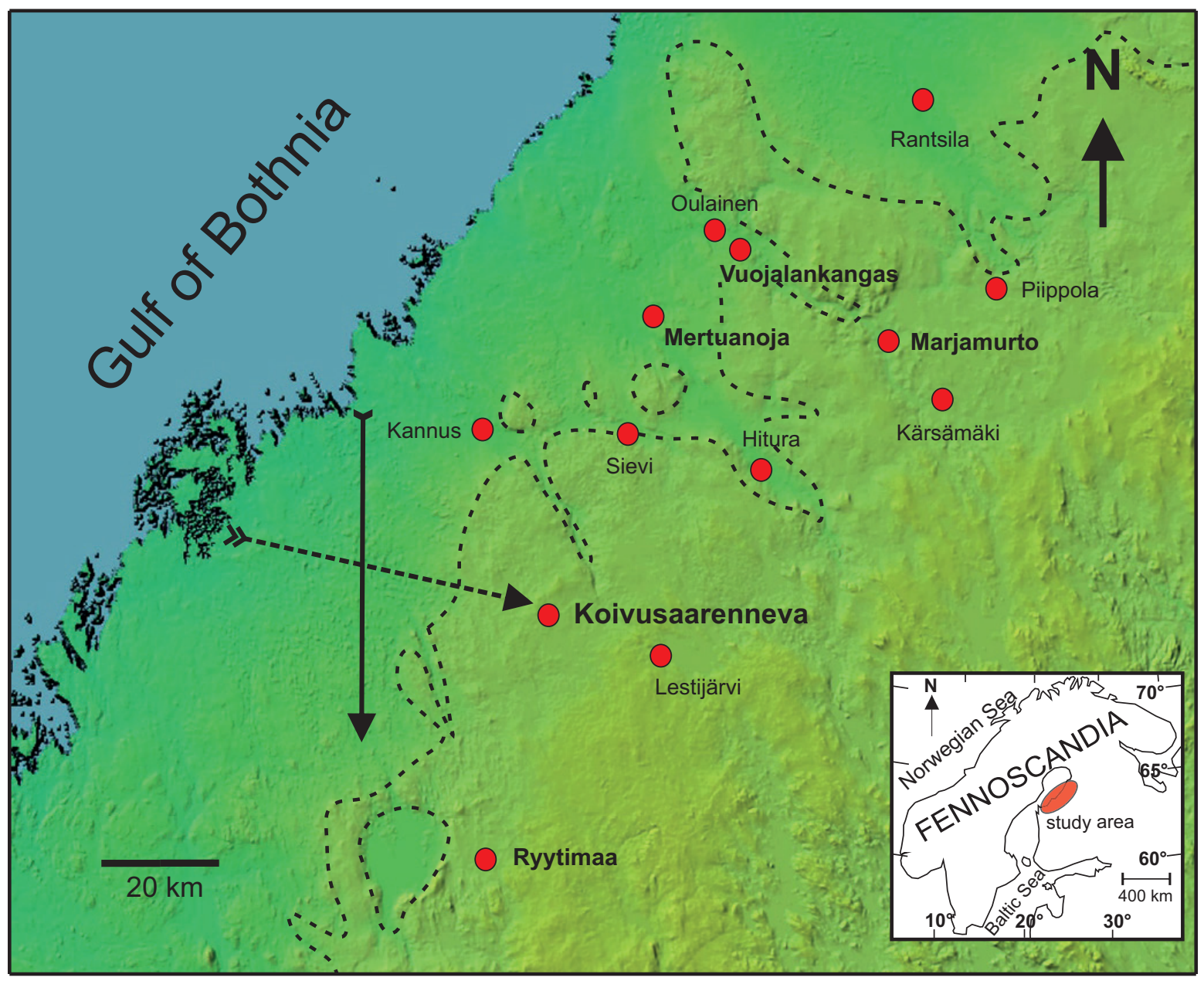

Fig. 1. Location map showing the study area (inset), the Koivusaarenneva site and adjacent sites discussed in text. The shaded DEM-map colours illustrate topographical features of the study area where green areas lie below $100 \mathrm{~m}$ a.s.l. and yellow areas above $100 \mathrm{~m}$ a.s.l. The black stippled line indicates $100 \mathrm{~m}$ a.s.l. contour. Two separate glacial lineation patterns can be clearly seen on the shaded DEM-image indicating an older ice flow from a westerly direction (stippled arrow) and a younger ice flow from a northerly direction (solid arrow). Base map (CThe National Land Survey of Finland $1 / 2016$. 
In the light of these observations, the aim of the present paper is to present lithostratigraphical, geochronological and biostratigraphical results of the sediment succession at the Koivusaarenneva site, central Ostrobothnia. The results obtained from the site are compared to other stratigraphically significant sites studied in central Ostrobothnia in order to shed light on the Weichselian glacial history of Finland.

\section{Study site and methods}

The Koivusaarenneva site is located on the outskirts of the town of Kokkola in Central Ostrobothnia, Finland (N 6334'54.9”, E 24¹3'52.8') (Fig. $1)$. The sections were opened in connection with a revitalized ilmenite ore project, during which a 170 $\mathrm{m}$ long, $40 \mathrm{~m}$ wide and up to $14 \mathrm{~m}$ deep pit was dug (Chernet, 1999). Here the ground surface altitude around the open pit is between 136 to 137 metres above present sea level ( $\mathrm{m}$ a.s.l.). The exposure was studied in 1999 and 2000.

Sedimentological techniques were applied to study exposed sediments, which could be differentiated into five sedimentary units that could be traced laterally in the section. Two wellexposed sediment successions were logged in detail, combined with overview studies around the pit. The thickness of each sediment unit identified and their textural and structural characteristics were recorded. Diamicton samples were taken for grainsize analyses and clast fabric measurements from diamcton units were carried out.

Clast-fabric analyses were performed measuring orientation and dip direction of a-axes of elongated clasts. However, the dip angle (dip direction of the plane defined by long-axis (a) and width-axis (b)) was not measured; only the sense of the dip direction was recorded. The true dip angle was not measured because an exact dip angle of a clast is often difficult to measure in sand- and gravel-rich diamicton (cf.
Andrews, 1971) and can lead to erroneous results when three-dimensional (3D) eigenvector statistics is applied to test the significance level of clast-fabric orientation. The clast-fabric results are presented as rose diagrams. In addition, fold axes' orientation and the dip direction of thrust planes from deformed sediments between diamicton units were measured and plotted using the lower hemisphere stereographic Schmidt equal-area projection.

The organic sediments encountered were analysed for their pollen content. The laboratory treatment followed conventional analysis methods described, for example, in Berglund \& RalskaJasiewiczova (1990). Six pollen samples were counted; the volume of sediment samples varied between 1 to $2 \mathrm{~cm}^{3}$ and the number of terrestrial pollen counted ranged from 550 to 650 in each sample.

At the Koivusaarenneva site, a unit of fine and medium sand, intercalated between two diamicton beds, was sampled for optically stimulated luminescence (OSL) dating. In addition, one sample was taken from fine sand in a fossil icewedge cast beneath a diamicton unit from the Early Weichselian reference section at Marjamurto in Haapavesi. The samples were taken by hammering an opaque, $30 \mathrm{~cm}$ long dark grey plastic tube (diameter $7 \mathrm{~cm}$ ) into the sediment. After extraction the tube was sealed with plastic caps and wrapped in aluminium foil. Sample preparation and OSL measurements were performed at the Nordic Laboratory for Luminescence Dating, Aarhus University in Risø, Denmark with a SAR dose protocol (Murray \& Wintle, 2000; 2003), following the procedure outline in detail in Lunkka et al. (2008). The dose rate was modified by including attenuation factors based on the saturated sediments' water content, internal alpha radiation and the estimated cosmic ray dose rate calculated from the assumed lifetime burial depths of the samples (cf. Prescott \& Hutton, 1994). 


\section{Results}

The southern and the northern pit faces of the Koivusaarenneva site were relatively well exposed at the time of investigation. The general stratigraphy can be divided into five sedimentary units above the crystalline bedrock (Fig. 2). These units are briefly described below.

Unit 1 is a silty sand, massive matrix-supported diamicton ranging from 4 to $14 \mathrm{~m}$ in thickness, resting on crystalline bedrock. The diamicton matrix is composed mostly of sand (51\%) and silt (40\%) of material less than $20 \mathrm{~mm}$. There are abundant larger clasts in the diamicton, ranging from 10 to $20 \mathrm{~cm}$ in diameter. A clast-fabric measurement shows a clear clast orientation and plunge towards $340^{\circ}(\log 1$, Fig. 2). This unit was observed in all pit walls.

$\underline{\text { Unit } 2}$ is 0.1 to $0.3 \mathrm{~m}$ thick and consists of interbedded fine sand, silt and silty clay with organic matter occurring as thin layers and lenses. The thickness of fine sand and silt/clay laminae range from 1 to $5 \mathrm{~mm}$. The unit can be traced along exposures but it is severely deformed (see description of unit 3 below) and/or eroded in parts. Six samples in a vertical succession over a 23 $\mathrm{cm}$ thick interval were sampled for pollen analysis. Tree pollen dominate the pollen spectra (90-95\% of the total pollen sum), of which Betula and Alnus are dominating species ranging from 40 to $45 \%$ each at sampled levels (Fig. 3). Pinus is constantly present increasing from $5 \%$ to $15 \%$ at the top of Unit 2. Corylus pollen (1.5-3.1\%) also occurs at every sampled level, while Picea (0.7-2.2\%) and Quercus pollen $(<0.7 \%)$ occur in most samples. In addition, Carpinus $(<0.5 \%)$, Fraxinus $(<0.2 \%)$, Fagus $(<0.2 \%)$ and Ulmus $(0.5 \%$ in one sample) occur occasionally in the pollen spectra, but their percentages are low. Shrubs and herbs constitute only 5 to $9 \%$ of the total pollen spectra over the interval studied. An OSL sample from the top part of the unit (horizontally laminated sand) gave an age of $105 \pm 8 \mathrm{ka}$ (Table 1 and Fig. 2).

Unit 3 is 1 to 2 metres thick, with a lower gradational contact to Unit 2 sediments, but in places rests directly on the Unit 1 diamicton. Internally, Unit 3 is a complex with interbedded silt and sand, occasional organic seams and wood fragments, out-sized pebble-grade clasts and few discontinuous layers of diamicton. All the sediments are deformed; measurements on recumbent thrust folds indicate an applied stress from $250^{\circ}$ (WSW) (Fig. 2).

Two clast fabric measurements on diamicton layers composed of silt, sand and out-sized clasts show randomly oriented clasts in the upper part of Unit 3 (see Log 1, Unit 3 in Fig. 2), while clast fabric on diamicton in the middle part shows a welldeveloped NW-trending orientation (see Log 2, Unit 3 in Fig. 2).

Unit 4 is a 1 to $1.5 \mathrm{~m}$ thick stratified sand diamicton, though silty at places in its lower part. The stratification arises from interbedded wellsorted sand and gravel layers and lenses. The lower contact is distinct and erosional, cutting fold structures in Unit 3. A clast fabric measurement shows an evident clast orientation and plunge towards the west (see Log 1, Unit 4 in Fig. 2).

Unit 5 is a 1 to $2.2 \mathrm{~m}$ thick, stratified brown diamicton with a coarse sand matrix and with an abundance of cobbles and boulders ( 0.5 to over 1.5 $\mathrm{m})$. Clasts are sub-angular and layers and lenses of gravel occur throughout the unit. The lower contact to Unit 4 is sharp. The Unit 5 diamicton differs distinctly from Unit 4 by its high content of boulders and cobbles and a coarser matrix. Due to the high boulder and cobble content, no clast fabric measurements were carried out in this unit. 


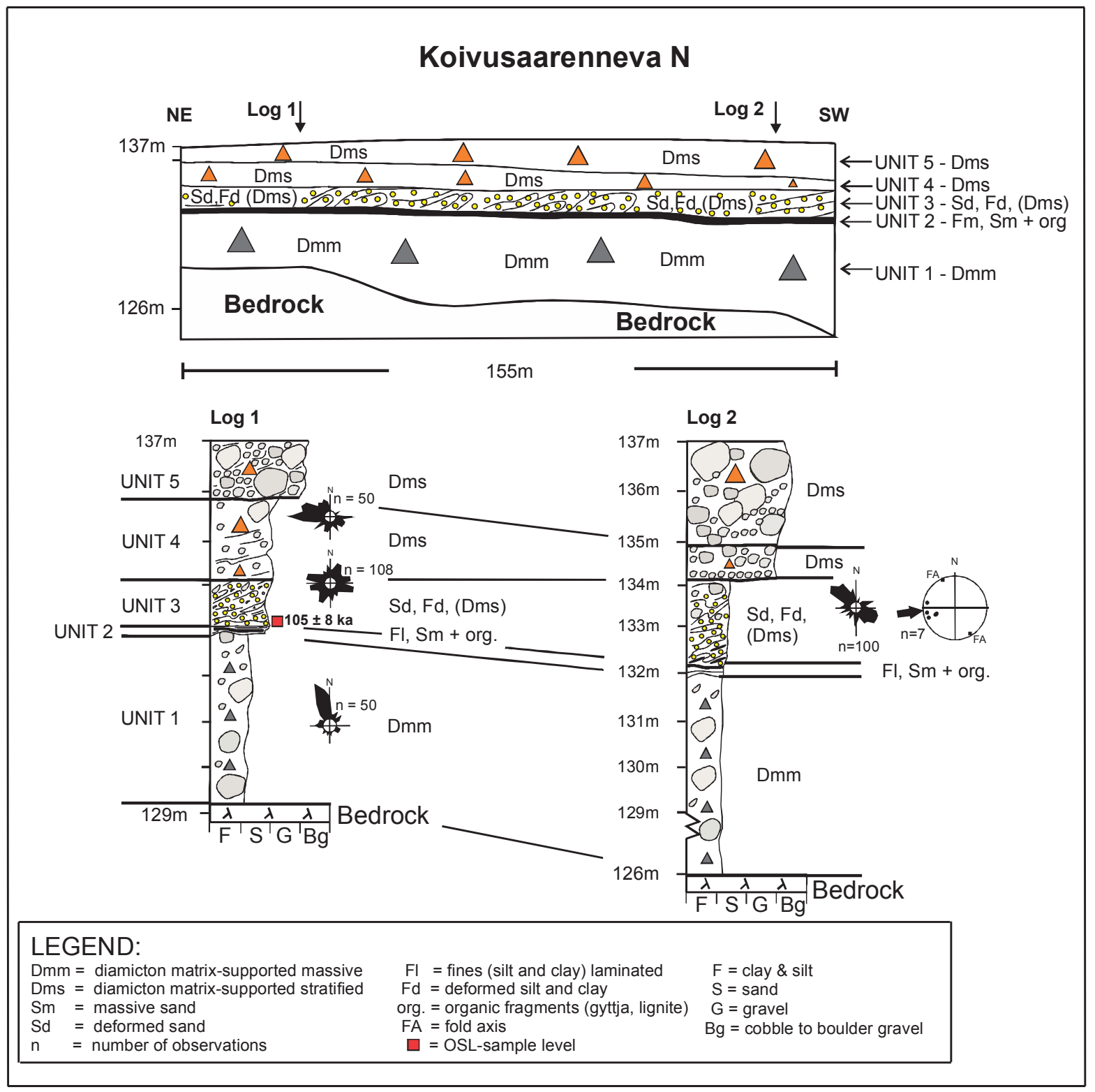

Fig. 2. A NW-SE section of the Koivusaarenneva pit, showing five lithostratigraphical units resting on the bedrock and the location of two sediment logs and their altitude above the present sea level. An OSL-date (105 \pm 8 ka, i.e. $105000 \pm$ 8000 years) was obtained from sand in the NE part of the exposure directly above Unit 2. Clast-fabric measurements from till units (rose diagrams) and fold axis (FA), as well as thrust-plane measurements (dots), with an arrow indicating stress direction are also shown in logs ( $n=$ number of observations). 


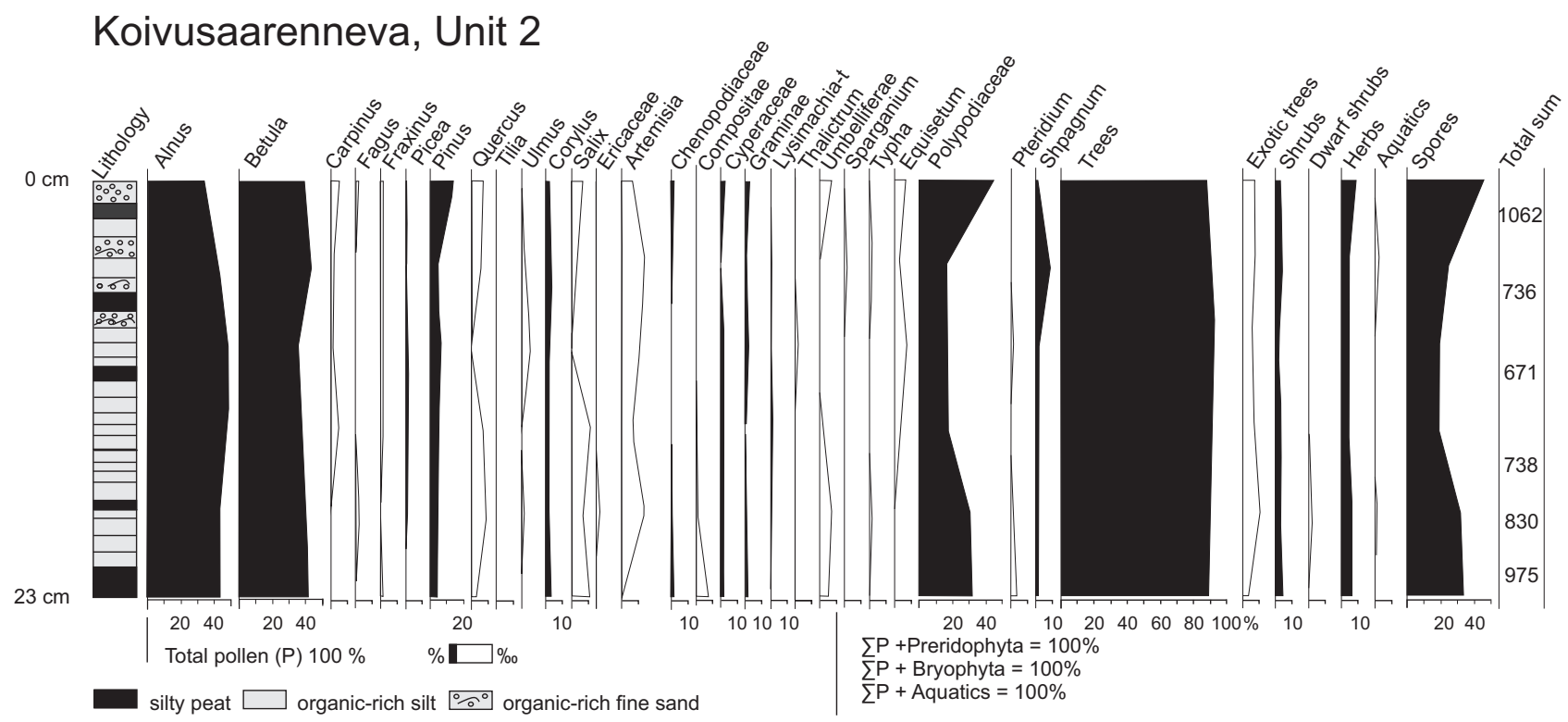

Fig. 3. Pollen diagram from the $26 \mathrm{~cm}$ thick, non-deformed basal part of Unit 2.

Table 1. OSL dating results from the Koivusaarenneva section and the Savaloja section in Marjamurto. The water contents of $16 \%$ and $21 \%$ are based on sediment (sand) pore-space percentages. It is estimated that the sand sediments sampled at both sites were under the groundwater table. Risø no. refers to the laboratory number given in the Nordic Laboratory of Luminescence Dating. The age is given in kiloyears (ka).

\begin{tabular}{|c|c|c|c|c|c|c|c|}
\hline Risøno. & Locality name & $\begin{array}{c}\text { Depth } \\
\mathrm{m}\end{array}$ & Dose, Gy & $\begin{array}{c}\text { Number of } \\
\text { measurements }\end{array}$ & $\begin{array}{c}\text { Dose rate } \\
\text { Gy/ka }\end{array}$ & Age, ka & w.c. \% \\
\hline 003201 & Koivusaarenneva & $4.0 \mathrm{~m}$ & $274 \pm 10$ & 24 & $2.61 \pm 0.15$ & $105 \pm 8$ & 16 \\
\hline 053207 & Marjamurto/Savaloja & $1.4 \mathrm{~m}$ & $210 \pm 9$ & 24 & $2.21 \pm 0.09$ & $95 \pm 6$ & 21 \\
\hline
\end{tabular}

\section{Interpretation}

Overall, the exposures at the Koivusaarenneva show five lithostratigraphical units above the crystalline bedrock (Fig. 2). Unit 1, a diamicton with a preferred clast fabric from NNW, is interpreted as basal till deposited during glacial flow from this direction.
The silt and sand with organic material (Unit 2) is interpreted to represent a shallow pond/ river flood plain deposit. The organic materials are most likely allocthonous material washed into the standing water body. Although the pollen spectra of the six samples taken in Unit 2 do not allow for any firm, in-depth interpretation of the vegetation succession, they clearly indicate that the area around 
the Koivusaarenneva site was forested during deposition of the sediments (Fig. 3). The arboreal pollen assemblage, dominated by birch and alder, show highly similar features to the Ostrobothnian regional pollen assemblage zone (P.A.Z) III (BetulaAlnus-Corylus zone) suggested for the Eemian Interglacial (Eriksson, 1993). According to that author, the Ostrobothnian regional P.A.Z. III of the Eemian interglacial, is characterized by high Alnus pollen values (20-60\%), Pinus pollen less than $20 \%$, low values of Picea pollen (less than 2\%), fluctuating Corylus pollen values from 5 to $20 \%$ and a few percent or intermittent occurrence of Quercus, Ulmus, Fraxinus pollen. These features can be clearly seen in the pollen spectra in Unit 2 at Koivusaarenneva (Fig. 3). This suggests that allocthonous organic material of Unit 2 might represent an interglacial flora incorporated in the sediments deposited at the site prior to $105 \pm 8 \mathrm{ka}$ ago, as indicated by the OSL age of the sediment directly above Unit 2 (Fig. 2). The present altitude of the organic-bearing stratum is $133-135 \mathrm{~m}$ a.s.l and the area was thus evidently in a supra-aquatic position also during the Eemian Interglacial, since the highest shore-line of the Eemian Sea in the area was at around 120-125 m a.s.l. in this area (cf. Grönlund, 1991).

The sands and silts of Unit 3, with included organic material, can be seen as a continuation of Unit 2, especially since there is a gradational lower contact between them. The sedimentological difference is the occurrence of diamicton lenses and a higher degree of post-depositional deformation of primary sediments, compared to Unit 2. The directional evidence of deformation, as shown from fold measurements and clast fabrics is interpreted to result from glacial deformation which suggest glacial stress from west to northwest. The same glacial overriding causing this deformation, is also suggested to be source for depositing the stratified diamicton of Unit 4, interpreted as basal till.

The stratified cobble- and boulder-rich diamicton of Unit 5 is interpreted as till, however it was not possible to determine its genesis because of its coarse texture. However, a distinct and sharp lower contact suggests that Unit 5 represents basal till that can be correlated uppermost till bed commonly encountered in the area, as discussed below.

\section{Stratigraphical correlation}

The sedimentary succession at Koivusaarenneva can be correlated to adjacent sequences in Ostrobothnia where Middle and Late Pleistocene sediments occur at a number of sites (cf. Lunkka et al., 2004; Johansson et al., 2011 and references therein).

It has been previously suggested that the socalled 'lower till' beneath the Early Weichselian interstadial or Eemian interglacial sediments in central and southern Ostrobothnia, with till clast fabric indicating an ice movement broadly from the NW, represents till deposited during the SaalianStage glaciation (cf. Lunkka et al., 2004; Johansson et al., 2011 and references therein). There are three representative sites in Ostrobothnia where the Saalian-age till is overlain by Eemian-age organic sediments (Aalto et al., 1989; Nenonen, 1995). At the Mertuanoja and Haapavesi sites, located c. 60 $\mathrm{km}$ north and $90 \mathrm{~km}$ northeast of Koivusaarenneva respectively (Fig. 1), the so-called Mertuanoja and Vesiperä Tills (Nenonen, 1995) underlying Eemian sediments were, according to the till-clast fabric measurements, deposited by the SIS from the NW $\left(310^{\circ}-320^{\circ}\right)$. According to Aalto et al. (1989), at the Ryytimaa section, Vimpeli, c. 50 kilometres SSW of the Koivusaarenneva site (Fig. 1), the so-called 'lower till' resting upon the bedrock and underlying the Eemian organic sediments was deposited during the Saalian glaciation from the SW.

At Koivusaarenneva, the diamicton at the base (Unit 1) is a correlative of these tills deposited during the Saalian glaciation (broadly correlated to Marine Isotope Stage MIS 6). This interpretation 


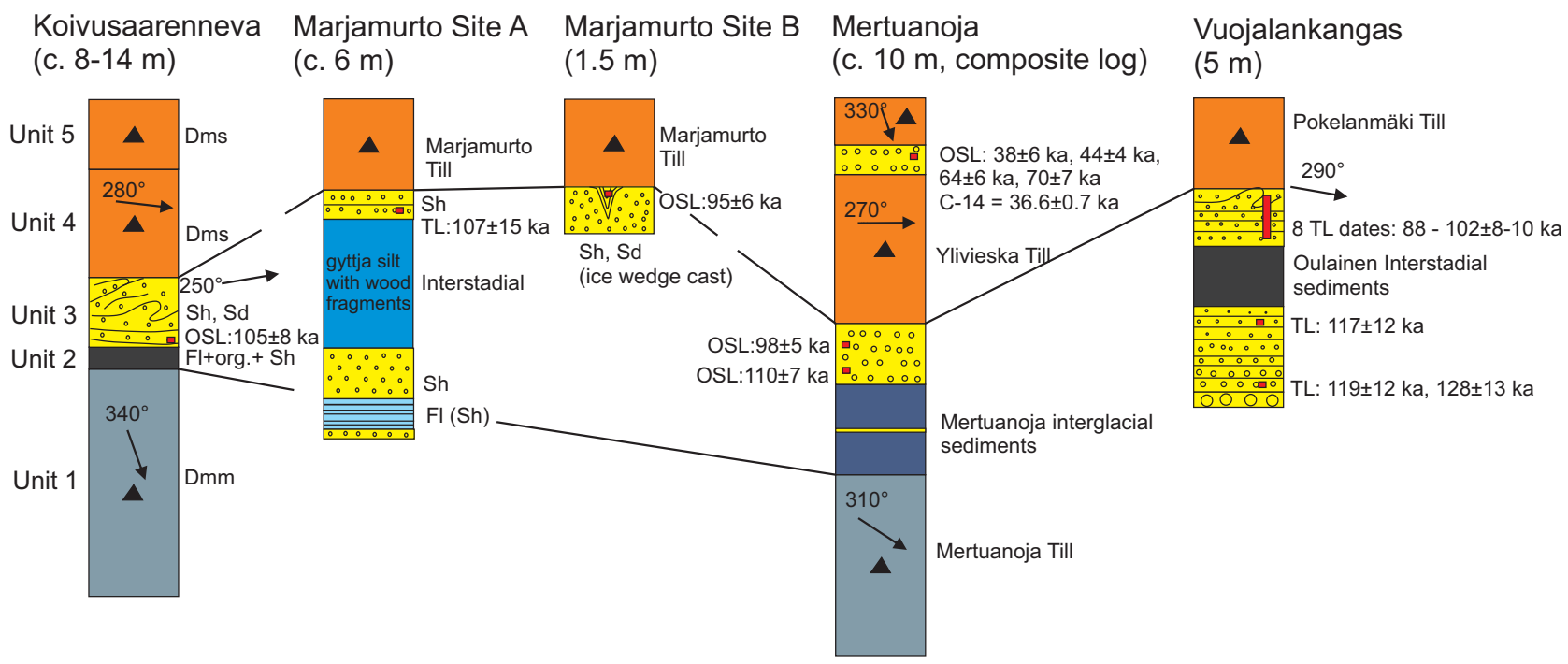

Fig. 4. Stratigraphical correlation scheme for the Koivusaarenneva section to the adjacent stratigraphically well-defined sediment sections at Marjamurto, Vuojalankangas and Mertuanoja. The arrows indicate the ice-movement direction deduced from till clast-fabric measurements. Geochronology is based on OSL and TL age determinations from different sand-rich units (red square), facies codes as in Fig. 2.

is also supported by the fact that it underlies interglacial- and interstadial-type sediments (Unit 2) which were deposited prior to $105 \pm 8$ $\mathrm{ka}$. Although the age estimate is based on only one OSL-date, the date obtained from Koivusaarenneva is comparable to the OSL-ages obtained from sands in similar stratigraphical position at the Marjamurto, Mertuanoja and Vuojalankangas sites (Fig. 4). The till-clast fabric measurements indicate that the ice movement direction at this stage was from $340^{\circ}$ at Koivusaarenneva and deviates only slightly from the Saalian ice-movement direction at the Mertuanoja, Haapavesi and Vimpeli areas (from $310^{\circ}-320^{\circ}$ ) (cf. Aalto et al., 1989; Nenonen, 1995).

The organic-bearing laminated silt and sand (Unit 2) overlying the Saalian till at the base (Unit 1) represents sediments most likely deposited during the Eemian-Stage interglacial. It is suggested here that the pollen spectrum in Unit 2 can be correlated to the Ostrobothnian regional P.A.Z III (Betula-Alnus-Corylus zone) for the Eemian interglacial (Eriksson, 1993). It is also possible that the upper part of Unit 2 that passes into fully glaciotectonically deformed sand and silt (Unit 3) were deposited during the Early Weichselian Brørup Interstadial (broadly correlated to MIS 5c) as indicated by the OSL-dated sand $(105 \pm 8 \mathrm{ka})$ at the top of Unit 2 (see Fig. 4).

There are number of sites in Ostrobothnia where Early Weichselian interstadial sediments occur (Fig. 4). The Marjamurto exposure in Haapavesi described by Peltoniemi et al. (1989), located 85 kilometres NE from Koivusaarenneva (Figs. 1 and 4), displays organic-bearing silt and sand and gyttja (a kettle-hole fill) on glaciofluvial sand and gravel overlain by fluvial sands and capped by a till unit. The pollen assemblage in the organic sediments at the Marjamurto site indicates that the sediments were deposited during an interstadial (Peltoniemi et al., 1989). Pollen evidence together with a thermoluminescence (TL) age of $105 \pm$ 15 ka from the sand unit at the top of organic sediment (gyttja) show that the Marjamurto interstadial sediments were laid down during the 
Early Weichselian Brørup Interstadial (Peltoniemi et al. 1989). An additional OSL sample taken at Marjamurto from cryoturbated fine sand within a fossil ice-wedge cast above was previously TL-dated fluvial sand. The OSL age obtained from fine sand in the fossil ice wedge below a till unit capping the section yielded an age $95 \pm 6 \mathrm{ka}$ (Fig. 4 and Table 1 ).

In addition to Marjamurto, a gyttja and peat unit occur at Vuojalankangas, Oulainen (Fig. 4). The organic sediments here were originally interpreted as of interglacial affinity (Forsström, 1982), but were subsequently re-interpreted as also being deposited during the Brørup Interstadial (Donner, 1983; Nenonen, 1995). Also at this site, both the pollen evidence and the TL-dating results (Jungner, 1987; see Fig. 4) suggest that the organic sediments were deposited during the Brørup Interstadial.

Although a detailed correlation between Koivusaarenneva and the interstadial sequences at Marjamurto and Vuojalankangas is not possible, the similar TL- and OSL ages obtained from sandy sediments imply that parts of the glaciotectonized sands and silts in Unit 3 might have been deposited during an ice-free interval, most likely during the Brørup Interstadial (MIS 5c).

The interstadial sediments (Unit 2) at Koivusaarenneva pass into deformed sand and silt (Unit 3) which are increasingly mixed in the upper part of Unit 3. This unit is overlain by basal till (Unit 4) with an erosional lower contact. Deformation structures in sand and silt (Unit 3) and the clastfabric results from the till above (Unit 4) clearly indicate that an ice movement from the west caused deformation in the interstadial sediments (Unit 3) and deposited the stratified basal till (Unit 4). Based on the data presented above, it is therefore evident that the western ice advance took place after the Brørup Interstadial.

Till stratigraphical studies carried out in the area around Koivusaarenneva and around the two other interstadial sites of Marjamurto and Vuojalankangas, Oulainen (Iisalo, 1992) indicate that there are frequently at least two till units, occasionally separated by sorted sediments, below the ground surface in central Western Finland (Fig. 5). For example, two till units occur in a 3.3 metre-deep excavation pit (site 471 in Fig. 5) only 10 kilometres SW of the Koivusaarenneva site. The till clast fabric in the upper, c. 2.2 metres thick sandy till unit shows NW-SE orientation of stones, while the silty sand till unit beneath displays a clear W-E orientation (Iisalo, 1992). Similarly, clast-fabric results from a number of test pits in Central and Northern Ostrobothnia show that the upper till unit beneath the ground surface has a strong NWSE orientation, while the clast fabrics in the lower till unit show a W-E orientation (see Fig. 5).

At least two till units also occur around the Marjamurto and Oulainen areas (Fig. 5). At the Marjamurto interstadial site, there is only one till bed above the interstadial unit indicating deposition broadly from the north (Peltoniemi et al., 1987; Iisalo, 1992). However, in the test pits dug around Marjamurto site there are two till beds, often separated with sorted sediments (Iisalo, 1992). The upper till, immediately underlying the ground surface, was deposited by ice from a northerly direction, while the lower unit was deposited from a westerly direction (Fig. 5). Unfortunately, no luminescence dates are available from the test-pit sections where these till beds are separated by sorted sediments. Likewise, the till stratigraphy in the Oulainen area also consists of two tills. Here the till clast-fabric measurements indicate a north-westerly (lower till bed, so-called Ruuna Till) and a westerly (the upper till bed, the so-called Pokelanmäki Till) ice-movement directions across the area (Nenonen, 1995). The Oulainen Interstadial sediments occur between these till units, although at the Vuojalankangas site, from where the Oulainen 


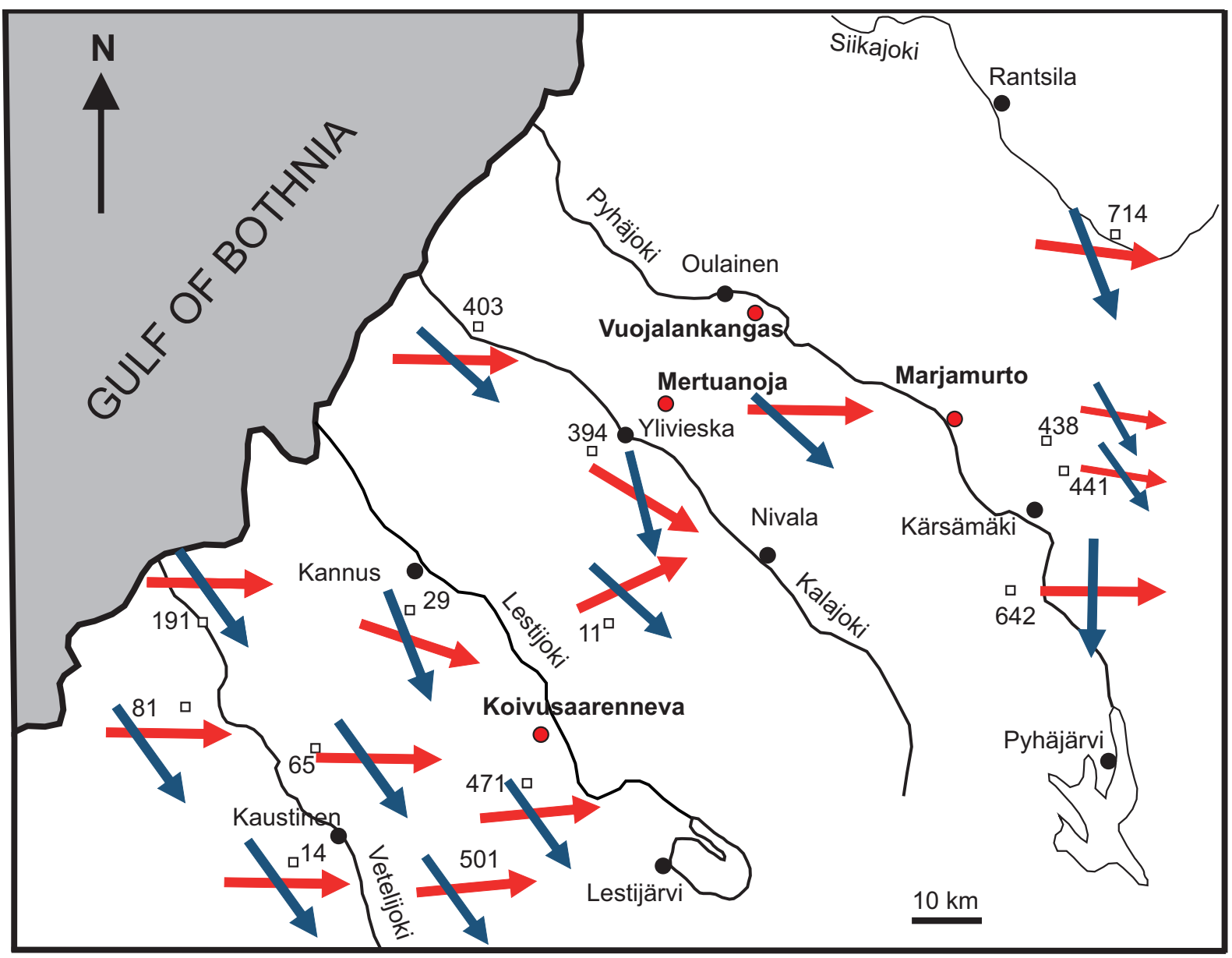

Fig. 5. A map of central and northern Ostrobothnia showing main rivers and lakes, as well as towns (black dots). The red dots indicate the location of the Koivusaarenneva, Mertuanoja, Vuojalankangas and Marjamurto sites. The white squares with numbers show the test pit sites where two till units, often separated with sorted sediments, occur (after lisalo 1992). The arrows indicate the older (red) ice-movement and the younger (blue) ice-movement direction deduced from till clastfabric measurements.

Interstadial sediments were originally described (Forsström, 1982), only the upper, Pokelanmäki Till, overlies the interstadial sediments (Forsström, 1982; Nenonen, 1995).

In addition to the till clast-fabric evidence of Unit 4 indicating an ice movement from the western direction, DEM- and LiDAR-images of landforms in western Ostrobothnia clearly indicate an older subglacial landform pattern which is orientated WNW to SSE. These landforms have been overridden by younger landform lineations orientated broadly from $\mathrm{N}$ to $\mathrm{S}$ (Fig. 6). 


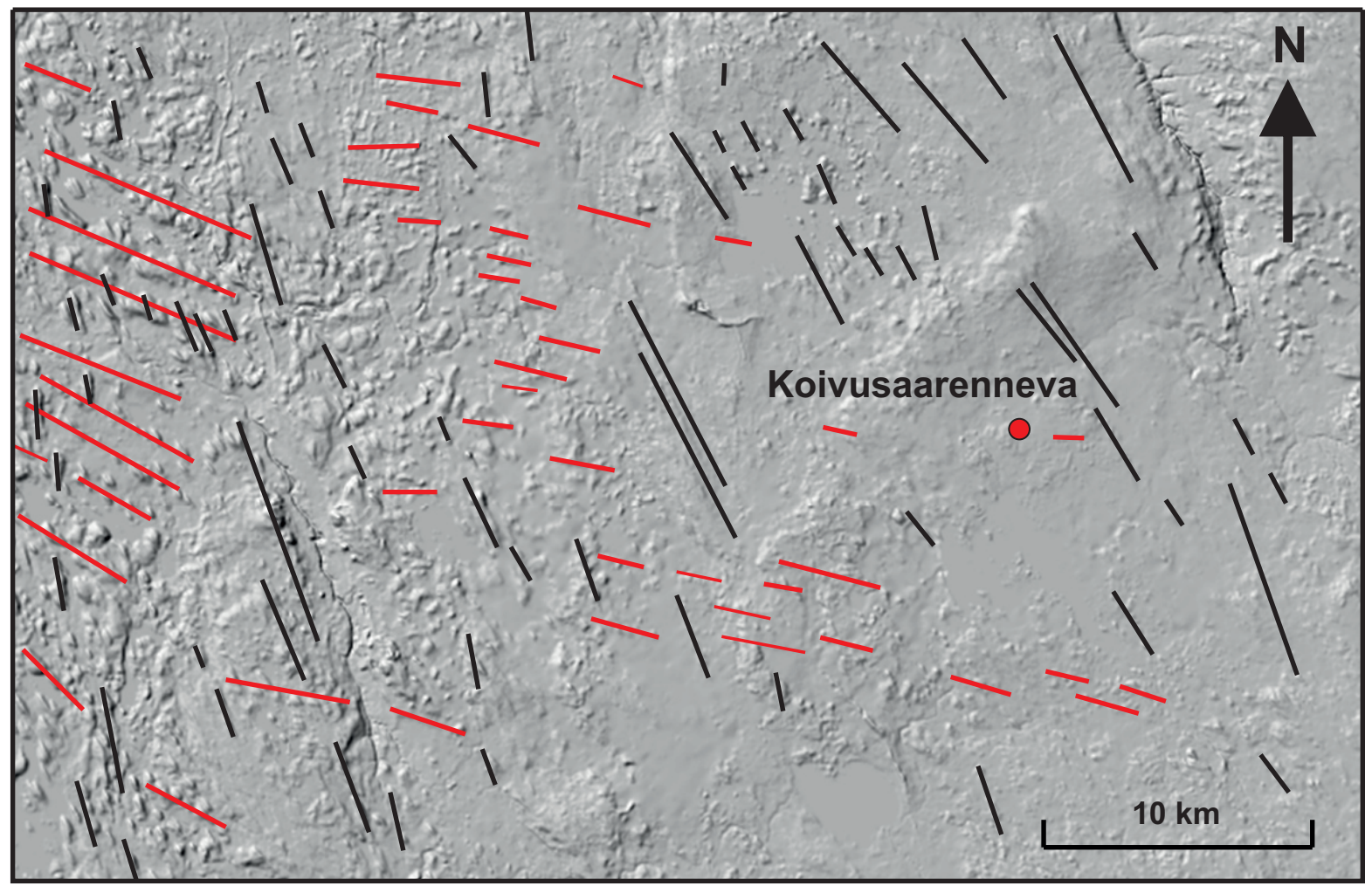

Fig. 6. A shaded DEM-map showing the area around the Koivusaarenneva site where the older subglacial lineations (red lines) from westerly direction are overridden by the younger subglacial lineations from northerly direction. Base map @ The National Land Survey of Finland 1/2016

All the evidence therefore indicates that following the ice-free Early Weichselian Brørup Interstadial, the SIS moved across the area from the W or WNW. However, it is not known precisely when this occurred. A commonly recorded, similar till unit in Central Ostrobothnia with clast-fabric measurements indicating ice movement from the west (Fig. 5) is thought to have been deposited either during the early Middle Weichselian (Nenonen, 1995; Iisalo, 2003) or during the Late Weichselian (Salonen et al., 2008) substages.

The youngest glacial landforms, such as drumlins which indicate the last ice movement, show that the glacial ice from the north - northwest (Fig. 6) deposited the uppermost till (cf. Iisalo, 1992, 2003; see Fig. 5). Therefore, it is highly likely that the uppermost till (Unit 5) in the Koivusaarenneva section was also originally deposited by ice which entered the area from a northerly/north-westerly direction. The sediment units at Koivusaarenneva correlate with adjacent, OSL-dated interstadial sites and at least two separate till units in the test pits, therefore suggesting that there were at least two ice advances across Central Ostrobothnia after the Brørup Interstadial. 


\section{Conclusions}

Based on the results presented from the Koivusaarenneva exposure in Central Ostrobothnia, the following conclusion can be drawn:

1) The lowest till (Unit 1), resting on the crystalline bedrock at Koivusaarenneva, represents till deposited by the SIS from the NNW during the Saalian-Stage glaciation $(\sim$ MIS 6$)$.

2) The organic-bearing silt and sand (Unit 2) with pollen assemblage correlative to the Ostrobothinian regional P.A.Z III (BetulaAlnus-Corylus zone) for the Eemian-Stage interglacial (Eriksson, 1993) suggests that Unit 2 was deposited during the Eemian Interglacial. However, the sediments, including their contained pollen, could have been redeposited. Nevertheless, Unit 2 was deposited prior to $105 \pm 8 \mathrm{ka}$.

3) The SIS advanced from the westerly direction severely deformed and eroded the early Weichselian and Eemian sediments (Unit 3) and deposited basal till (Unit 4) after $105 \pm 8 \mathrm{ka}$. This ice advance from the west took place most probably during the early Middle Weichselian (Schalkholz Stadial, MIS4).

4) Based on the orientation of aligned landforms and till stratigraphical studies carried out in the study area and adjacent areas, the uppermost till (Unit 5) at Koivusaarenneva was deposited from the northerly direction and it is thought to have been deposited during the Late Weichselian substage.

5) The sedimentary succession at Koivusaarenneva in common with the stratigraphical evidence from adjacent areas, clearly indicates that there must have been at least two Weichselian ice advances across Central Ostrobothnia after the Brørup Interstadial (MIS 5c).

\section{Acknowledgements}

Juha Pekka Lunkka received financial support for the OSL-dating and additional field work rechecking the key interstadial sites in central and northern Ostrobothnia from the Finnish Academy project no 210909. Eiliv Larsen and an anonymous reviewer are thanked for their comments and M. Lunkka and P. Gibbard are thanked for checking the English.

\section{References}

Aalto, M., Donner, J., Hirvas, H. \& Niemelä J., 1989. An interglacial beaver dam deposit at Vimpeli, Otsrobothnia, Vimpeli. The Geological Survey of Finland, Bulletin 348, $34 \mathrm{p}$.

Andrews, J.T., 1971. Techniques of Till Fabric Analysis. Technical Bulletin No. 6. British Geomorphological Research Group. 43 p.

Berglund, B.E. \& Ralska-Jasiewiczova, M., 1990. Pollen analysis and pollen diagrams. In: Berglund, B.E. (ed.) Handbook of Holocene Palaeoecology and Palaeohydrology, pp. 455-484.

Boulton, G.S., Hagdorn, W., Maillot, P.B. \& Zatsepin, S., 2009. Drainage beneath ice sheets: groundwater-channel coupling, and the origin of esker systems from former ice sheets. Quaternary Science Reviews 28, 621-638. https://doi.org/10.1016/j.quascirev.2008.05.009

Chernet, T., 1999. Applied mineralogical studies on the Koivusaarenneva ilmenite deposit, Kälviä and other selected titanium dioxide pigment raw materials. Geological Survey of Finland, Special Publications 32, 77 p.

Cuzzone, J.K., Clark, P.U., Carlson, A.E., Ullman, D.J., Rinterknecht, V.R., Milne, G.A., Lunkka, J.-P., Wohlfarth,B., Marcott, S.A. \& Caffee, M., 2016. Final deglaciation of the Scandinavian Ice sheet and implications for the Holocene global sea-level budget. Earth and Planetary Science Letters 448, 34-41. https://doi.org/10.1016/j.epsl.2016.05.019

Donner, J., 1983. The identification of Eemian interglacial and Weichselian interstadial deposits in Finland. Annales Academiae Scientiarum Fennicae Series IIIA 136, 38 p.

Donner, J., 1995. The Quaternary History of Scandinavia. World and Regional Geology 7. Cambridge University Press. Cambridge, UK. 199 p.

Eriksson, B., 1993. The Eemian pollen stratigraphy and vegetational history of Ostrobothnia, Finland. Geological Survey of Finland, Bulletin 372, 36 p. 
Forsström, L., 1982. The Oulainen Interglacial in Ostrobothnia, western Finland. Acta Universitatis Ouluensis, Series A, Scientiae Rerum Naturalium 136, Geologica 4, 116 p.

Forsström, L., 1984. Eemian and Weichselian correlation problems in Finland. Boreas 13, 301-318. https://doi.org/10.1111/j.1502-3885.1984.tb01126.x

Grönlund, T., 1991. The diatom stratigraphy of the Eemian Baltic Sea on the basis of sediment discoveries in Ostrobothnia, Finland. Geological Survey of Finland, Report of Investigation 102, 26 p.

Helmens, K., 2014. The Last Interglacial - Glacial cycle (MIS 5 -2 ) re-examined based on long proxy records from central and northern Europe. Quaternary Science Reviews 86, $115-143$. https://doi.org/10.1016/j.quascirev.2013.12.012

Iisalo, E., 1992. Observations on the stratigraphy of Weichselian tills and subtill eskers in central Ostrobothnia, Finland. Geological Survey of Finland, Reports of Investigation 112, 42 p.

Iisalo, E., 2003. Till stratigraphy and geochemical diffrences between till beds in western Finland. In: Räisänen, M. \& Nikkarinen, M. (eds), Complexity of glacial dispersal and hydromorphic processes in till geochemistry. Geological Survey of Finland, Special Paper 34, pp. 21-42.

Iverson, N.R., 2010. Shear resistance and continuity of subglacial till: hydrology rules. Journal of Glaciology 56, 1104-1114. https://doi.org/10.3189/002214311796406220

Johansson, P., Lunkka, J.P. \& Sarala, P., 2011. Glaciation of Finland. In: Ehlers, J. \& Gibbard, P. L., Hughes, P.D. (eds), Developments in Quaternary Science, vol.15. Elsevier, Amsterdam, The Netherlands, pp. 105-116. https://doi.org/10.1016/b978-0-444-53447-7.00009-x

Jungner, H., 1987. Thermoluminescence dating of sediments from Oulainen and Vimpeli Otsrobothnia, Finland. Boreas 16, 231-235. https://doi.org/10.1111/j.1502-3885.1987.tb00090.x

Kleman, J. \& Hättestrand, C., 1999. Frozen-bed Fennoscandian and Laurentide ice sheets during the Last Glacial Maximum. Nature 402, 63-66. https://doi.org/10.1038/47005

Larsen, E., Kjær, K.H., Demidov, I., Funder, S., Grøsfjeld, K., Houmark-Nielsen, M., Jensen, M., Linge, H. \& Lyså, A., 2006. Late Pleistocene glacial and lake history of northwestern Russia. Boreas 35, 394-424. https://doi.org/10.1080/03009480600781958

Larsen, E., Fredin, O., Jensen, M., Lyså, A., Kuznetsov, D. \& Subetto, D., 2014. Subglacial sediment, proglacial lake level and topographic controls on ice extent and lobe geometries during the Last Glacial Maximum in NW Russia. Quaternary Science Reviews 92, 369-387. https://doi.org/10.1016/j.quascirev.2013.02.018
Lunkka, J.P., Saarnisto, M., Gey, V., Demidov, I. \& Kiselova, V., 2001. Extent and age of the Last Glacial Maximum in the southeastern sector of the Scandinavian Ice Sheet. Global and Planetary Change 31, 407-425.

https://doi.org/10.1016/s0921-8181(01)00132-1

Lunkka, J.P., Johansson, P., Saarnisto, M. \& Sallasmaa, O., 2004. Glaciation of Finland. In: Ehlers, J. \& Gibbard, P.L. (eds), Quaternary Glaciations - Extent and Chronolog, Part I: Europe. Elsevier, Amsterdam - Tokyo, pp. 93-100. https://doi.org/10.1016/s1571-0866(04)80058-7

Lunkka, J.P., Murray, A. \& Korpela, K., 2008. Weichselian sediment succession at Ruunaa, Finland indicating a MidWeichselian ice-free interval in eastern Fennoscandia. Boreas 37, 234-244. https://doi.org/10.1111/j.1502-3885.2007.00021.x

Murray, A.S. \& Wintle, A.G., 2000. Luminescence dating of quartz using an improved single-aliquot regenerativedose protocol. Radiation Measurements 32, 57-73. https://doi.org/10.1016/s1350-4487(99)00253-x

Murray, A.S. \& Wintle, A.G., 2003. The single aliquot regenerative dose protocol: Potential for improvements in reliability. Radiation Measurements 37, 377-381. https://doi.org/10.1016/s1350-4487(03)00053-2

Nenonen, K., 1995. Pleistocene Stratigraphy and Reference Sections in Southern and Western Finland. Geological Survey of Finland. Kuopio. 205 p.

Peltoniemi, H., Eriksson, B., Grönlund, T. \& Saarnisto, M., 1989. Marjamurto, an interstadial site in a till-covered esker area of central Ostrobothnia, western Finland. Bulletin of the Geological Society of Finland 61, 209237.

Pitkäranta, R., Lunkka, J.P. \& Eskola, K.O., 2013. Lithostratigraphy and Optically Stimulated Luminescence age determinations of pre-Late Weichselian deposits in the Suupohja area, western Finland. Boreas 43, 193-207. https://doi.org/10.1111/bor.12030

Prescott, J.R. \& Hutton, J.T., 1994. Cosmic ray distributions to dose rates for luminescence and ESR dating: Large depths and longterm variations. Radiation Measurements 23, 497-500. https://doi.org/10.1016/1350-4487(94)90086-8

Punkari, M. \& Forsström, L., 1995. Organic remains in Finnish subglacial sediments. Quaternary Research 43, 414-425. https://doi.org/10.1006/qres.1995.1047

Räsänen, M.E., Huitti, J.V., Bhattarai, S., Harvey III, J. \& Huttunen, S., 2015. The SE sector of the Middle Weichselian Eurasian Ice Sheet was much smaller than assumed. Quaternary Science Reviews 122, 131-141. https://doi.org/10.1016/j.quascirev.2015.05.019

Saarnisto, M. \& Salonen, V.-P., 1995. Glacial history of Finland. In: Ehlers, J., Kozarski, S. \& Gibbard, P. L. (eds), Glacial Deposits in North-East Europe. Balkema, Rotterdam, the Nettherlands, pp. 3-10. 
Saarnisto, M. \& Lunkka, J.P., 2004. Climate variability during the last interglacial-glacial cycle in NW Eurasia. In: Battarbee R.W., Gasse F. and Stickley C.E. (eds), Past Climate Variability through Europe and Africa. Kluwer Academic Publishers, Dordrecht, the Netherlands, pp. 443-464.

https://doi.org/10.1007/978-1-4020-2121-3_21

Salonen, V.-P., Eriksson, B. \& Grönlund, T., 1992. Pleistocene stratigraphy in the Lappajärvi meteorite crater in Ostrobothnia, Finland. Boreas 21, 253-269.

https://doi.org/10.1111/j.1502-3885.1992.tb00031.x

Salonen, V-P., Kaakinen, A., Kultti, S., Miettinen, A., Eskola, K.O. \& Lunkka, J.P., 2008. Middle Weichselian glacial event in the central part of the Scandinavian Ice Sheet recorded in the Hitura pit, Ostrobothnia, Finland. Boreas $37,38-54$. https://doi.org/10.1111/j.1502-3885.2007.00009.x

Sarala, P., 2005. Weichselian stratigraphy, geomorphology and glacial dynamics in southern Finnish Lapland. Bulletin of the Geological Society of Finland 77, 71-104.
Svendsen, J.I., Alexanderson, H., Astakhov, V.I., Demidov, I., Dowdeswell, J.A., Funder, S., Gataullin, V., Henriksen, M., Hjort, C., Houmark-Nielsen, M., Hubberten, H.W., Ingólfsson, Ó., Jakobsson, M., Kjær, K.H., Larsen, E., Lokrantz, H., Lunkka, J.P., Lyså, A., Mangerud, M., Matiouchkov, A., Murray, A., Möller, P., Niessen, F., Nikolskaya, O., Polyak, L., Saarnisto, M., Siegert, C., Siegert, M.J., Spielhagen, R. \& Stein, R., 2004. Late Quaternary ice sheet history of northern Eurasia. Quaternary Science Reviews 23, 1229-271. https://doi.org/10.1016/j.quascirev.2003.12.008

Ukkonen, P., Lunkka, J.P., Jungner, H. \& Donner, J., 1999. New radiocarbon dates of Finnish mammoths indicate large ice-free areas in Fennoscandia during the Middle Weichselian. Journal of Quaternary Science 14, 711-714. https://doi.org/10.1002/(sici) 1099-1417(199912) 14:7<711::aid-jqs506>3.0.co;2-e

Wohlfarth, B., 2013. A review of Early Weichselian climate (MIS 5d-a) in Europe. Technical Report TR-13-03. Svensk Kärnbränslehantering AB-Swedish Nuclear Waste management CO. Stockholm, Sweden. 79 p. 